\title{
Modelling the impact of climate change on cereal yield in Morocco
}

\author{
Faiz Mourad ${ }^{1}$, Laamari Abdelali² ${ }^{2}$ Lakhyar Zouhair $^{3}$ \\ ${ }^{1} \mathrm{PhD}$ Student on Economics. LMMCE,Faculty of Law, Economics and Social Sciences Settat-Morocco \\ ${ }^{2}$ Researcher on Agricultural economics. Dryland Research CenterSettat Morocco \\ ${ }^{3}$ Professor of Social Economics. Faculty of Law, Economics and Social Sciences Settat-Morocco
}

\begin{abstract}
To assess the impact of climate change different studies were conducted in several regions of Morocco. The assessment of climate change and its impacts involves the simulation of a range of different socio-economic and physical processes. Some of these processes are well known such temperature, rainfall, storms, etc.., others not. Hence for each modeling step researchers need to consider what is known, what is not known, and how climate change can be expressed.This paper is a contribution to research on climate change impact on cereal yield in the last 50 years. The application of the multiple linear regression model to a set of time series of yield, rainfall, temperature and storm has generated significant coefficients that can explain the relation between yield and the three climate variables. The model output confirms the results of the previous studies of yield variability. The positive effect of rainfall and the negative one of storm and temperature ware recorded. Above the three factors, temperature and storms have a negative effect on cereal yield. So more efforts on germplasm, crop management and agricultural policy measures are needed to alleviate the impact of climate change. An estimate coefficient of -4.943 for temperature is very indicating the high impact of temperature on yield. The $R^{2}$ is around 0.45 indicates that more than $55 \%$ of total yield variability is explained by other factors than rain, temperature and storm.
\end{abstract}

Keywords-Climate, Rainfall, Temperature, Multiple regression, Cereals.

\section{INTRODUCTION}

Food security in the world and especially in poor countries must be deeply investigated. According to the $\mathrm{FAO}^{1}$, more than 795 million people worldwide suffer from hunger, which represents one in nine of our planet's inhabitants, the majority of them are from developing countries. Thus, subSaharan Africa is the region with the highest prevalence of hunger. Indeed, $25 \%$ of its population is undernourished. This situation will be exacerbated by a number of factors,

\footnotetext{
${ }^{1}$ FAO, 2015 « L'étatd'insécuritéalimentairedans le monde The state of food insecurity in the world) »
}

including population explosion, depletion and degradation of fertile soil, and the impacts of climate change (CC) on agriculture. $\mathrm{CC}$ is the most difficult factor to manage because of the various factors to be considered (temperature, rainfall, storms and drought).

In addition, the relationship of impact of climate change on food security through affecting agricultural production has been addressed by several methods and in various contexts. Howden et al. (2007) estimated that climatic events can account for $15 \%$ to $35 \%$ of the overall yield change in wheat, oilseeds and coarse grains. Challinor et al. (2014) predicted reductions in wheat yield by $45 \%$ in tropical regions and $15 \%$ in temperate zones.

A study conducted by the World Bank and FAO in collaboration with Moroccan institutions has contributed to predict the impacts of climate projections on the yields of major crops until 2080, based on two scenarios Development of the IPCC: (A22) ${ }^{2}$ and (B22) ${ }^{3}$. The results ${ }^{4}$ indicated that after 2030, and considering the current level of technology, irrigated crops, especially fruits and vegetables, will benefit from climate change. On the other hand, rainfed crops will be negatively affectedby climatic variations. It estimates that from 2050rainfedcereals and vegetable yields will decrease by $5 \%$, rainfed wheat and barley yield by $20 \%$, and rainfed yields by $30 \%$. Yield of winter rainfed crops, namely cereals, vegetables and oil crops.

Morocco, like other countries characterized by a generally semi-arid climate, is considered among the countries most

\footnotetext{
2 Pessimistic scenario of demographic growth and economic inequality, polluting technologies and protectionism.

${ }^{3}$ Optimistic scenario based on local solutions enabling economic, social and environmental viability; Reasoned demographic growth, slower and more diversified technological change, regionalized and more environmentally friendly development.

4 Mélanie Requier-Desjardins (2010), «Impacts des changements climatiques sur l'agriculture au Maroc et en Tunisie et priorités d'adaptation (Impacts of climate change on agriculture in Morocco and Tunisia and adaptation priorities)»CIHEAM No56 - Mars 2010.
} 
vulnerable to climate change (Giorgi, 2006) ${ }^{5}$. Several studies have been carried out by national and international bodies to study the impact of climate change on agriculture in Morocco. So, following these findings and in order to contribute to the quantification of the impact of climate change on agriculture in Morocco, an econometric model is applied to a time series on climate factors and yield to explain climate change. The main factors used are annual mean temperature, average rainfall and storm frequency as explain factors and cereal yield trend as variable to be explained. The specific objectives of this research are to quantify the relationship of each climate change factor and the yield of cereal crops and try to explain the weight this impact.

\section{IMPORTANT DATA ON MOROCCAN AGRICULTURE}

According to the official statistics of the Ministry of Agriculture $^{6}$, Morocco recorded, in normal years, about 29 billion $\mathrm{m}^{3}$ of useful rain in average. Only 20 billion $\mathrm{m}^{3}$ of the rain is mobilized (16 billion as surface water and 4 billion from groundwater). This important potential in terms of rain makes Moroccan agriculture directly dependent on climate conditions. Indeed, more than $80 \%$ of the Useful Agricultural Area (8.7 million hectares) available to Morocco is occupied by rainfed crops. Thus, graph 1 below shows that $83 \%$ of the areais located in rainfed agricultural ecosystem. Although the strategies and measures of the Moroccan government in the last 20 years are stimulating irrigated agriculture. More efforts of the government are targeting the rational use of water in agriculture; Green Morocco Plan has developed projects for Pillar I to be supported through this strategy. The new Water Economic Plan is one of the power tool used to enhance investment in irrigated agriculture using drip irrigation.

Moreover, cereal crops are the most dominant agricultural activities in Morocco, particularly in rainfed regions, since it occupies more than half of the area. Graph 2 shows that cereal crops occupy $52 \%$ of total area, followed by fallow with $20 \%$, fruit trees with $15 \%$ and finally forages, food legumes and vegetables occupying respectively 5,4 , and $3 \%$ of area. Cereal area is distributed among Chaouia, Abada, Haouz, Tadla, Gharb and Saïs regions (MAPM, 2014).

${ }^{5}$ F.Giorgi(2006) «,Climatechangehot-spots». Geophysicalresearchletters, vol.33,2006.

6 MAPM, 2014 «L'agriculture du Maroc en chiffres Moroccan agriculture in figures )(». www.mapm.gov.ma
Graphe1: Distribution of agriculural area by water sources in Morocco

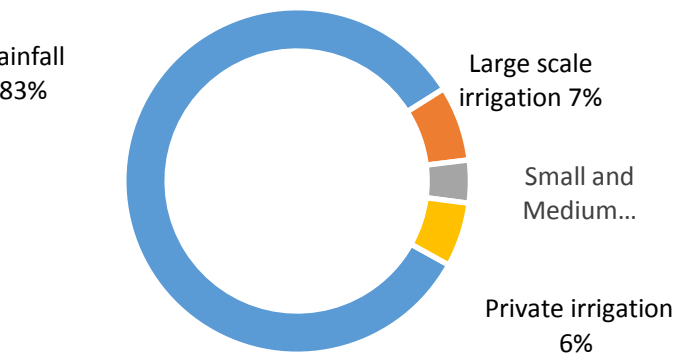

Graphe 2: Distribution of agricultural area in Maroc

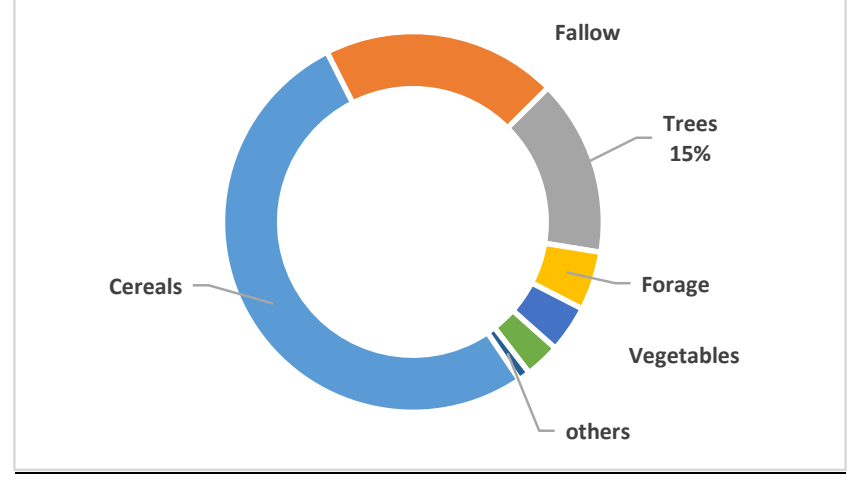

Data Source: MAPM ( www.mpam.gov.ma)

\section{TEMPERATURE, RAINFALL AND YIELD OF CEREAL CROPS IN MOROCCO}

Trend analyses of yield and rainfall for Morocco during 1961 to 2016 period is presented in graph 3 and in table 1 . It's clear that significant variation of temperature is recorded during the period and coefficient of variation is about $26 \%$ (Table1). With a coefficient of variation about $38 \%$, rainfall the variation is very high. For cereals the coefficient of variation is about $46 \%$.It's important to notice that different studies have showed that yield variability can be, partly, explained by technology. Belaid and al. (2005) have estimated that net wheat growth yield depends on variety used and weather effect. 
Graph 3: Cereal yield and rainfall trends

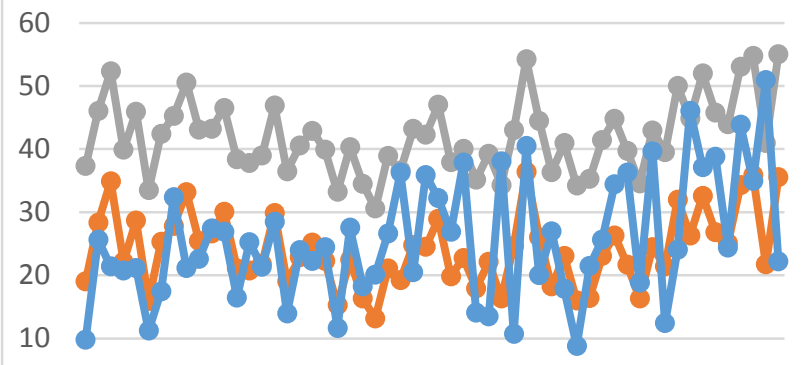

0

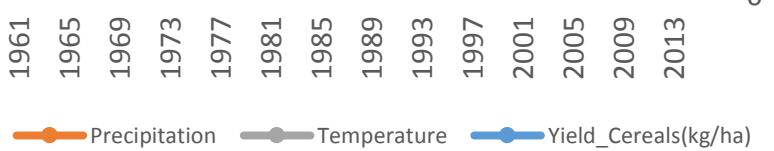

Table.1 : Characteristics of temperature, precipitation and yield of cereals

2000

1500

1000

500

\begin{tabular}{|l|c|c|c|}
\hline Min & 366,6 & 13,15 & 16,45 \\
\hline Max & 2122,4 & 36,39 & 19,47 \\
\hline Coeff.Var & 0,46 & 0,38 & 0,26 \\
\hline $\begin{array}{l}\text { Standard } \\
\text { deviation }\end{array}$ & 410,2 & 5,79 & 0,66 \\
\hline
\end{tabular}

Data Source: (BM: http://databank.banquemondiale.org) and (http://fr.tutiempo.net/climat/maroc.html)

\section{ECONOMIC MODEL AND RESULTS}

As mentioned at the top of this article, graph 3 shows two important findings, grain yield variation and rainfall variability have the same trends. Also grain yield and temperature have almost reversed peaks.

In order to better understand these findings and to analysethe relationships that are likely to explain the impact of climate change on yields, we try to model cereal yield as a function of factors explaining climate change.

\section{A. The context and objectives of the study}

To assess the impact of climate change different studies were conducted in several regions of Morocco. It's important to stress that Morocco is involved in climate change negotiations under the umbrella of the United Nation and has to present communication on the situation that occurs in Morocco, so the government is conducting several studies using macroeconomic analyses tools and others. Several studies have been conducted to explain and analyze the impact of climate change on agriculture based on the rainfall factor. Indeed, Barakat and Handoufe (1998) linked the decline in agricultural production to the accumulated rainfall deficit at the mid cropping season. Stour and Agoumi used a spatial and temporal analysis of temperature and precipitation variations to explain global warming. Ouraich and Tyner (2014) have developed a regionalized Morocco computable general equilibrium model to analyse the linkages of climate-induced productivity losses (gains) at the level of administrative and economic regions in Morocco. The World Bank in collaboration with national and international scientists have conducted a deep research on climate change impacts on crop yields in Morocco (2008). Most of these studies confirm that climate projections on Morocco show gradually increasing aridity because of reduced rainfall and higher temperatures. It is necessary to keep in mind that climate models best predict averages rather than extreme values. In Morocco aridity will increase and, thus will have negative effectson agricultural yields. In our case, cereals are more vulnerable to climate change and will be seriously affected.

So this research is a contribution to all these studies with specificity of using empirical model that can link climate change (temperature, rainfall and storm frequency) to cereal yield.

The global objective of this study is to study the impact of climate change on cereal production and assess their negative effects on the yield. It is important to test the relationship that may exist between cereal crop yields trend and the main climate change factors, namelytemperature, rainfall and storm frequency.

\section{B. Research approach}

\section{Data collection}

A secondary data based on official statistics published by national and international administration (Ministry of Agriculture, National Office for Food Legume and Cereals, etc..) on cereal trends, temperature, rainfall and storm frequency number of storm days for the period 1980 to 2016 of Morocco.

\section{Multiple linear regressionmodel}

Multiple linear regression is the most common form of linear regression analysis. As a predictive analysis, the multiple linear regression is used to explain the relationship between one continuous dependent variable and two or more independent variables. The independent variables can be continuous or categorical (dummy). There are three major uses for multiple linear regression analysis. The first, it can be used to identify the strength of the effect that the independent variables have on a 
dependent variable. Second, it can be used to forecast effects or impacts of changes, which is our case. That is, multiple linear regression analysis helps us to understand how much will the dependent variable change when we change the independent variables. Third, a multiple linear regression analysis predicts trends and future values. The multiple linear regression analysis can be used to get point estimates. The use of the model can define if we have a predictive or prescriptive one.

When selecting the multiple linear regression analysis, we assume that's the model fit. Adding independent variables to a multiple linear regression model will always increase the amount of explained variance in the dependent variable (expressed by $\mathrm{R}^{2}$ ). Therefore, adding too many independent variables without any theoretical justification may result in an over-fit model. The assumptions related to the use of this kind of model are:

- Regression residuals must be normally distributed.

- A linear relationship is assumed between the dependent variable and the independent variables.

- The residuals are homoscedastic and approximately rectangular-shaped.

- Absence of multicollinearity is assumed in the model, meaning that the independent variables are not too highly correlated.

In the case of this study we have selected the three major factors that can inform on the impact of climate change on cereal yield. The net impact of climate change variables using econometric model was possible by modeling the yield variability as a dependent variable and rain, temperature and storms as independent variables. A multiple linear regression model was estimated using ordinary least squares procedure. The model is then written as follows:
Yield $=f($ Rain, Temp, Storms $)$

With:

- Yield: is a continuous quantitative variable, representing the yield of cereals in Morocco expressed in kg per ha.

- Rain: is a continuous quantitative variable, it represents the average rainfall of each year in $\mathrm{mm}$;

- Temp: is a continuous quantitative variable, it represents the average temperature of each year in ${ }^{\circ}$ $\mathrm{C}$;

- Storms: is a discrete quantitative variable, representing the number of storm days in each year.

According to the type of the variables to be used, and after verifying the necessary assumptions (linearity, normality, multi-collinearity, etc...), the use of a multiple linear regression function seems to be appropriate for this case. The following computer programs were used: Excel, SPSS, STATA $\ldots$ to run the model and descriptive statistics.It should be noted that even in the case of zero temperatures or zero rainfall and zero storms in a given year, we can have a substantial amount of cereal yields due to irrigation. This led us to include a constant in the model. Then our model becomes:

$$
\begin{aligned}
\text { yield }_{\text {cereals }}= & \alpha_{0}+\alpha_{1}(\text { Rain })+\alpha_{2}(\text { Temp }) \\
& \left.+\alpha_{3} \text { (Storms }\right) \\
\text { with } & : \alpha_{0}, \quad \text { is the constant } ;
\end{aligned}
$$

$\alpha_{1}, \alpha_{2}$, et $\alpha_{3}$ are the contribution coefficients to be estimated

\section{Results and Discussions}

Table 2 shows the model output and indicates that $\mathrm{F}$ value is about 8.895 and significant at $p<0.005$. Then we have to reject $\mathrm{H}_{0}$. According to that, there is a statistically significant relationship between the dependent variable and the independent variables. We can therefore conclude that the model with predictor better predict the dependent variable than the model without predictors.

Table.2: Model outputs: Relevance of the equation ANOVA ${ }^{a}$

\begin{tabular}{|l|l|r|r|r|r|r|}
\hline \multicolumn{2}{|l|}{ Model } & Sum of squares & DF & Average squares & F & Sig. \\
\hline \multirow{3}{*}{1} & Regression & 3,179 & 3 & 1,060 & 8,895 &, $000^{\mathrm{b}}$ \\
\cline { 2 - 8 } & Residues & 3,932 & 33 &, 119 & & \\
\cline { 2 - 8 } & Total & 7,111 & 36 & & & \\
\hline
\end{tabular}

a. Dependent Variable: Yield

b. Predicted values: (constants), Storm_trans, temp_trans, rain_trans

Table.3: Model's output summary ${ }^{b}$

\begin{tabular}{|l|r|r|r|r|r|}
\hline Model & \multicolumn{1}{|c|}{$\mathrm{R}$} & R-square & R-square adjusted & Standard error & \multicolumn{1}{c|}{ Durbin-Watson } \\
\hline 1 &, $669^{\mathrm{a}}$ &, 447 &, 397 &, 34516 & 1,837 \\
\hline
\end{tabular}

a. Predicted values: (constants), Storm, temp, rain

b. Dependent variable: Yield_trans

From Table 3 , the value of the multiple correlation coefficients is 0.669 . Then the value $\mathrm{R} \approx 0.70$ indicates that the data set is well adjusted to the model. The value $\mathrm{R}^{2} \approx$ 0.45 informs us that the independent variables explain 
about $45 \%$ of the variability of the model. The adjusted value of $\mathrm{R}^{2} \approx 0.40$ confirms that the robustness of the model is about $40 \%$ even if we consider another sample from the same population. The Durbin-Watson is equal to 1.837; witch is close to 2 , so the $\mathrm{H} 0$ of absence of autocorrelation of the errors is accepted.

Table.4: Model outputs: Regression coefficients

\begin{tabular}{|l|l|c|c|c|c|c|}
\hline \multicolumn{2}{|l|}{ Model } & \multicolumn{2}{|c|}{$\begin{array}{c}\text { Not standardized } \\
\text { coefficient }\end{array}$} & $\begin{array}{c}\text { standardized } \\
\text { coefficient }\end{array}$ & \multirow{2}{*}{ Sig. } & \\
\cline { 3 - 5 } \multicolumn{2}{l|}{} & A & Standard Error & Beta & & \\
\hline \multirow{4}{*}{1} & (Constant) & 19,853 & 5,798 & & 3,424 &, 002 \\
\cline { 2 - 7 } & Rain &, 775 &, 227 &, 451 & 3,413 &, 002 \\
\cline { 2 - 7 } & Temp & $-4,943$ & 2,034 &,- 321 & $-2,431$ &, 021 \\
\cline { 2 - 7 } & Storm &,- 459 &, 172 &,- 350 & $-2,665$ &, 012 \\
\hline
\end{tabular}

a. Dependent variable :Yield_cereal

From Table 4, we can conclude the following results:

- The last column indicates that all coefficients are significant at $5 \%$ probability level. Then, all independent variables contribute significantly to the explanation of the variability of the model.

- The standardized coefficients of "rain", which represents rainfall contributes positively to the explanation of yield variability with a relative weight of $45 \%$;

- The independent variable "temp" contributes negatively to the explanation of the dependent variable "Yield" with a relative weight of 32\%;

- The independent variable "Storm" contributes negatively to the explanation of the dependent variable "Yield" with a relative weight of the order of $35 \%$.

The non-standardized coefficients (A) allow us to reconstruct the equation of the regression line of our model. Then it is written as follows:

$$
\begin{gathered}
\text { Yield }=19,853+0,775(\text { rain })-4,943(\text { Temp }) \\
-0,459(\text { Storm })
\end{gathered}
$$

The model output confirms the results of the previous studies offactors that affect yield variability. It's important to notice that the model explain more than $45 \%$ of yield variability and, for sure production technology explains the rest. Among the variables which have been proposed temperature and storms it's important to notice here negative impacts on cereal yield however few studies were conducted on that issues. Agricultural research like all innovators is interested in developing appropriate technologies such as drought tolerant varieties, no-till technology and others. So it's important to integrate research projects on climate criteria that can affect the potential of cereal crops.

According to the model outputs and climate behaviour in Morocco, specific actions must be considered. Storms frequency in the mountain regions, low rainfall and high temperature in the arid and semi-arid regions can be considered in targeting government agricultural development interventions.

\section{CONCLUSION}

In the setting at hand, the multiple linear regression applied with the purpose of identifying climate factors that affect cereal yield in Morocco. A time series of more than 50 years of the variables used in the model was used. Even the use of a linear regression it seems that climate change has a significant effect on cereal yields.

The results presented have clearly demonstrated a significant link between the main factors explaining climate change, namely temperature, rainfall and frequency of storms on the one hand and the yield of cereals as a dependant variable. By stating that an annual average temperature increase of $1 \%$ may cause a $32 \%$ decrease in cereal crop yields, or only $1 \%$ decrease rain may result in a $45 \%$ decrease of yield, and an increase of $1 \%$ of the occurrence of storms per year can cause a $35 \%$ decrease of cereal yield. Temperature has the high coefficient to the others meaning that hot seasons are more frequent and are usually associated to drought. If we consider the drought of 80 's we had this climate phenomena whichhad severe impact not only on cereals but also on livestock.

It's important to notice that the use of such tool is possible since data are available at the ministry of agriculture and each regional representative of the ministry has its own staff for data collection and management. Modelling climate impact can help making appropriate interventions and policies. These results therefore converge with the alarming forecasts and figures that have been putby several national and international bodies in relation with climate change assessment and its impact on Moroccan agriculture.

\section{REFERENCES}

[1] A.CHÉBIL, N.MTIMET and H.TIZAOUI. (2011). «Impact du changement climatique sur la productivité des cultures céréalières dans la région 
de Béja (Tunisie) ». AfJARE Vol.6 N² Septembre 2011.

[2] A.MAROUANI and M.GHARBI. (1999). «Etude des rapports des pluies saisonnières et annuelles avec les rendements et la production des céréales dans les régions subhumides et semi-arides de la Tunisie $»$.MEDIT, $\mathrm{N}^{\circ} 2,1999$.

[3] CHALLINOR and al. (2014). « A meta-analysis of crop yield under climate change and adaptation». Nature Climate Change 4,287-291, 2014.

[4] D. SMADHI, L .ZELLA. (2012). « Variabilité de la pluviométrie et son impact sur la production céréalière au nord de l'Algérie. Période (19702009) ».Sciences \& Technologie, C - N³5 Juin (2012).

[5] E.Z.MAHMALAT and A.BENNIS. (2012). «Environnement et Changement Climatique au Maroc - Diagnostic et Perspectives» KonradAdenauer-Stiftung. E.V., Bureau au Maroc, Association Ribat Al Fath pour le développement durable, Rabat, Mai 2012

[6] F. BENAMMAR.(1996). «La culture des céréales dans la région semi-aride tunisienne du Kef», MEDIT, N³ /96, PP 58-60.1996.

[7] F.GIORGI. (2006).« Climatechangehot-spots ».Geophysicalresearchletters. vol.33.2006.

[8] F.BARAKAT and A. HANDOUFE. (1998). «Approche agro-climatique de la sécheresse agricole au Maroc» Sciences et changement planétaire /sécheresse, Volume 9, numéro 3, Septembre, 1998.

[9] FAO. (2015). «L'état d'insécurité alimentaire dans le monde » www.fao.org

[10] G.C.NELSON and al. (2009). «Changement climatique Impact sur l'agriculture et coûts de l'adaptation» Institut international de recherche sur les politiques alimentaires IFPRI Washington, D.C. Octobre 2009.

[11] H.BENAOUDA and R.BALAGHI. (2009).«Les changements climatiques: Impacts sur l'agriculture au Maroc».Symposium international «Agriculture durable en région méditerranéenne (AGDUMED) » Rabat, Maroc, 14-16 Mai 2009.

[12] HLPE.(2012).« Sécurité alimentaire et changement climatique». Rapport du Groupe d'experts de haut niveau sur la sécurité alimentaire et la nutrition du Comité de la sécurité alimentaire mondiale, Rome, 2012.

[13] L.STOUR and A. AGOUMI. (2009). « Sécheresse climatique au Maroc durant les dernières décennies », Hydroécol. Appl. (2008) Tome 16, pp. 215-232, EDP Sciences, 2009.
[14] M. WALSH and al. (2008). «The Effects of Climate Change on Agriculture, Land Resources, Water Resources, and Biodiversity in the United States». Synthesis and Assessment Product 4.3 Report by the U.S. Climate Change Science Program and the Subcommittee on Global Change Research, May 2008.

[15]M.BADRAOUI and R.BALAGHI. (2012). «L'adaptation de l'agriculture marocaine au changement climatique » Konrad-AdenauerStiftung. Rabat, 2012.

[16]M.MERDAS. (1997). «Modèle agrométéorologique de prévision des rendements des céréales au Maroc». Rapport final, AGRIMA, CRTS/04.

[17] M.REQUIER-DESJARDINS. (2010). " Impacts des changements climatiques sur l'agriculture au Maroc et en Tunisie et priorités d'adaptation » Les Notes d'analyse du CIHEAM, N56, Mars 2010.

[18]M.T. MOULINEand al. (2011). «Le Maroc face au changement climatique Incidences sur la trajectoire de développement et perspectives d'adaptation » Rapport stratégique de synthèse. IRES, Février 2011.

[19] O.DESCHENES and M.GREENSTONE. (2007). " The Economic Impacts of Climate Change: Evidence from Agricultural Output and Random Fluctuations in Weather». The American Economic Review, Vol.97 N 1 , March 2007.

[20] R. Mendelsohn. (2009). "The Impact of Climate Change on Agriculture in Developing Countries». Journal of Natural Resources Policy Research, Vol. 1, No. 1, 5-19, January 2009.

[21] S.M.HOWDEN and al. (2007).« Adapting agriculture to climate change» PNAS December 11, 2007 vol. 104 no. 50 19691-19696 AG.

[22] S.MANSOURI and L.RADHOUANE. (2015). «Dynamique du climat et impact sur la production d'orge dans la zone de Béja au nord-ouest de la Tunisie » European Scientific Journal.Edition vol.11. N.9. March 2015.

[23]Z .BOUAZZA, M.JALIL, R.CHAFIL and A.ZEROUALI. (2002). «Vulnérabilité et adaptation du secteur irrigué du Maroc face aux impacts des changements climatiques ». Revue H.T.E. $\mathrm{N}^{\circ} 124$ Septembre / Décembre 2002.

[24] http://fr.tutiempo.net/climat/maroc.html

[25] http://www.agriculture.gov.ma

[26] http://www.databank.banquemondiale.org

[27] http://www.marocmeteo.ma

[28] http://www.onicl.org.ma 